\title{
REMITTANCE AND ECONOMIC GROWTH: SOUTH ASIAN PERSPECTIVE
}

\author{
Syed Shoeb Ahmed \\ Assistant Professor, Hamdard University, Karachi, Pakistan. \\ Sumair Farooq \\ Assistant Professor, Hamdard University, Karachi, Pakistan. \\ Raja Muhammad Ali \\ Assistant Professor, Hamdard University, Karachi, Pakistan. \\ Sobia Iqbal \\ University of Karachi, Karachi, Pakistan.
}

\begin{abstract}
South Asian economies are largely based on remittances. Every year a large number of migrants migrate from their countries to different destination and they send remittances to their home lands. This research presents a strong relationship between remittances and economic growth of South Asian countries. Some of the researches have been conducted on the remittances in South Asia and most of them focused on two categories either on the migration or on the flow of remittances in the South Asian countries. But this study attempted to provide a view not only on the flow of remittances over the last decade but also established connections between flow of remittances and economic growth in South Asian countries.

This research conducted on three important countries of South Asia namely: India, Bangladesh and Pakistan. The main objective of this research is to determine inwards flow of remittances and its impact in terms of national and local levels on these countries. The expected finding of this research will be the facts that the selected countries' financial condition largely dependent on remittances sent by their overseas diasporas.
\end{abstract}

Keywords: Migrants, remittance, economic growth, overseas diaspora.

Cite this Article: Syed Shoeb Ahmed, Sumair Farooq, Raja Muhammad Ali and Sobia Iqbal, Remittance and Economic Growth: South Asian Perspective, International Journal of Management 11(12), 2020, pp. 818-824.

http://iaeme.com/Home/issue/IJM?Volume=11\&Issue=12 


\section{INTRODUCTION}

A noticeable change has been noted in remittances through the people who leave their home country which brings change in the economy of origin countries also brings the positive prospects for the receiving countries. It seems very difficult to evaluate the impact of remittances because their outcomes are diverse at different levels. According to study: "Many analysts use the gross amount of remittances to developing countries to highlight their importance relative to official development assistance and other financial flows. But this is misleading, since the gross figures do not take into account the transfers that migrants make to rich countries, and those that take place between developing countries. When these "reverse flows" are taken into account, the net amount received by developing countries is much smaller" (IOM, 2005).

The inward remittances are the major means of foreign exchange particularly for those countries which are considered financially weak where the inflow of remittance is more than the combined level of foreign direct assistance ( FDA) and foreign direct investment ( FDI) as per the study (Newland, 2005). It has found that there is big contribution of remittances by foreing communities in economy (Klooster, 2005).

The amount of remittances have positive impact on the source country relating to balance of payment, increment of GNP which bring rise to luxurious articles. The constant inflow of remittances has been very important in increasing export items, enhancement of country's wealth and easing foreign exchange complication. It is said that they are deemed to be affecting in development and economic firmness.

\section{LITERATURE REVIEW}

The volume of remittances can increase in spending by change in amount of investment. It has found that remittance could bring economic development if it is channeled into productive development (Ratha, 2007). It has also found that remittances reduce credit constraints and work as alternative financial system in underdevelopment financial system (Paola \& RuizArranz, 2006).

The impact of remittances on economic growth has proved to be positive by now, for instance, during the period of 1980 to 2004, sample of 39 developing countries had positive impact on the growth of economy (Pradhan, Upadhyay, \& Upadhyaya, 2008). It is also suggested that there is no impact upon economy, though not denying the poverty alleviation and change in consumption capacity on receiver (IMF, 2009).

According to studies, remittance inflow have counterbalance the trade shortfall and able to maintain accounts surplus for some large receiving countries (Mohapatra et al. 2010). There is contribution of remittances towards GDP growth rate. That's why, most of countries opting for the source of capital from their Diaspora outside the country as there is now strong awareness relating to remittances as source of external finance. As per study, some countries such as Srilanka, Nepal and Philippines considering the issuance of remittance bond (Mohapatra, 2010).

It has found that the flow of remittances has negative impact along with positive impact. On one hand, international migration income opportunity, rapid economic development, change in living conditions, infrastructural development, on the other hand, it bring about class distinctions, income disparity, and culture leg among remittance recipient and nonrecipient countries. It has also been discussed in the development discourse of Bangladesh .In Middle East, severe economic crises occurred for South Asian countries. Despite the fact that their export to industrialized zone reduced, slowdown in import provide support to contain trade and current account deficit. In 2009, financial crises in the Middle East caused concern 
to all remittance recipient countries in South Asian region. Yet, this concern was short term due to strong resilience from remittance continued to remain strong (UNESCAP, 2010). In another study concluded that economic growth is stimulated by enhancement of remittances for some receiving countries (Matuzeviciute and Butkus2016) and (Meyer and Shera 2016). In 2017, the amount of 466 billion USD representing over $70 \%$ from the worldwide flows which is remittances sent home by workers from developing countries (World Bank, 2016) . Some other consider that "If remittances are countercyclical, then they could help smooth macroeconomic fluctuations, and if they are procyclical, they could amplify business cycle fluctuations". (De, Islamaj, Kose, and Yousefi 2016)

\subsection{Objectives}

- It is to study the remittances' trends for some of South Asian countries.

- It is to study the remittance's impact upon economic growth of selective countries of South Asia.

- It is to study of effect of inward remittances at macro and micro level.

Based on the particular objectives that have been researched, the following hypotheses were formulated:

\subsection{Hypothesis}

Hi: There has been increase in the volume of inflow of remittances over the period of time.

Hii: Increase in remittances has major impact upon stabilizing the economic growth.

\subsection{Methodology}

In the cross-sectional study, the descriptive model has been used with different aspects including: inflow of remittances and remittances 'impact of three selective countries. A qualitative analysis has been used and discussed .Also, both primary and secondary sources data have been taken for information. It is important to mention that quantative aspect also considered for showing migration and remittances trends relating to objectives of the study.

In addition to this, a questionnaire has been formulated and administrated personally and through email from the representatives of different organization such as State Bank of Pakistan, Applied Economics and Research Centre of Pakistan, Ministry of Overseas ,Pakistan and Overseas Foundation Pakistan and their responses have been sought in terms of 'Expert Opinion ".

\section{REMITTANCES' TRENDS IN SOUTH ASIA}

According to the literature, Indian is among those countries which received big amount of remittances across South Asia. The Indian remittances inflow has gone towards higher side during the last decade. India received nearly $\$ 80$ billion of overseas remittances this year with GDP ratio $7.7 \%$ - a 16\% leap from last year's $\$ 69$ billion in 2017. India holds its higher position, with remittances expected to total $\$ 80$ billion, followed by China $\$ 67$ billion, Mexico and the Philippines \$34 billion each, and Egypt \$26 billion this year.

Bangladesh holds a prominent position in top remittance recipient countries in the world. Remittances sent by Bangladeshi Diaspora have major contribution to increase gross domestic product. In 1990, Migration outflow accelerated in but it got slow-moving in 2000 due to the occurrence of nine eleven. But again it got enhanced in the upcoming times. There has been a notable rise in remittances which enhanced foreign currency reserves. According to a World Bank report, Bangladesh has been recognized as the ninth highest recipient of remittances this year with $\$ 15.9$ billion with GDP ratio $7 \%$ in 2018, which ranks third in South Asia-after India whose remittance is $\$ 80$ billion and Pakistan which ranked $\$ 20.9$ billion. 
There has been increase in remittance inflow after nine eleven. The increase was observed significantly .In 2002, approximate $\$ 2.3$ billion recorded which was doubled than in the year 2000 and it reached up $\$ 19.3$ billion in 2015 according to World Bank. In 2018, Pakistan received \$20 billion according to the same sources. There was little pause observed in remittance inflow due to some economic down turn in Middle East, as a result, some Pakistani workers were lay off from their work. However, this impact was replaced by the migrant workers aspired for new destinations especially in emerging market. There is one more reason which conveys that global economic crisis did not impact the flow of remittances to Pakistan which is weakening of Pakistani currency implied the consumer's surplus increased when buying was done locally in Pakistan.

\section{ANALYSIS OF REMITTANCE TRENDS}

\subsection{India's Remittance Trend}

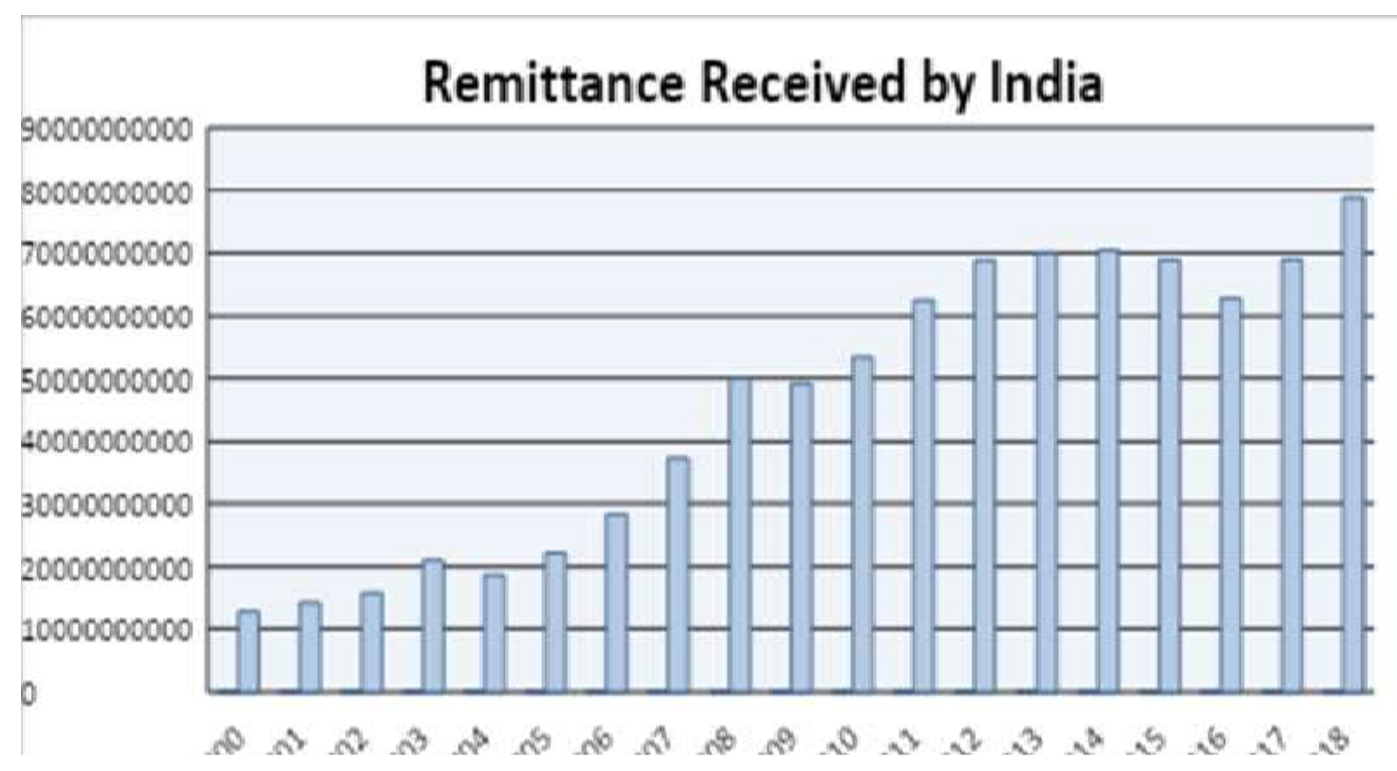

Figure 1.India's remittance trend

Source: Author's estimate

If we observe trend of India for the last two decades, it can be observed that from 2000 to 2015, there increasing trend as per the analysis of World Bank and Pew research report. India has received nearly $\$ 12$ billion for remittances in 2000, $\$ 54$ billion in 2010 and nearly $\$ 70$ billion in 2015 in foreign remittance which was highlighted in repot, released by Pew Research Centre. (http://www.pewglobal.org/2015). This trend steadily escalated and it reached up $\$ 80$ billion in 2018.

\subsection{Bangladesh's Remittance Trend}

Bangladesh received $\$ 1.9$ billion in 2000. It increased steadily up to 2012 which was approximately \$ 14 billion, but there was small pause in the flow of remittances in 2013 which was 2.3 percent. The reasons for this slowing down pace were political changes, civil war eruption, unstable economic conditions of UAE and Libya. In 2014, remittances again increased and reached up to $\$ 14.9$ billion. Again, it got steady pace and reached up to nearly $\$ 16$ billion in 2018. According to study, Bangladesh is the only country in South Asia due to large official remittances where domestic -currency value has increased beside all the major currencies amidst the existing world economic crises (Rihan.S.2009) 


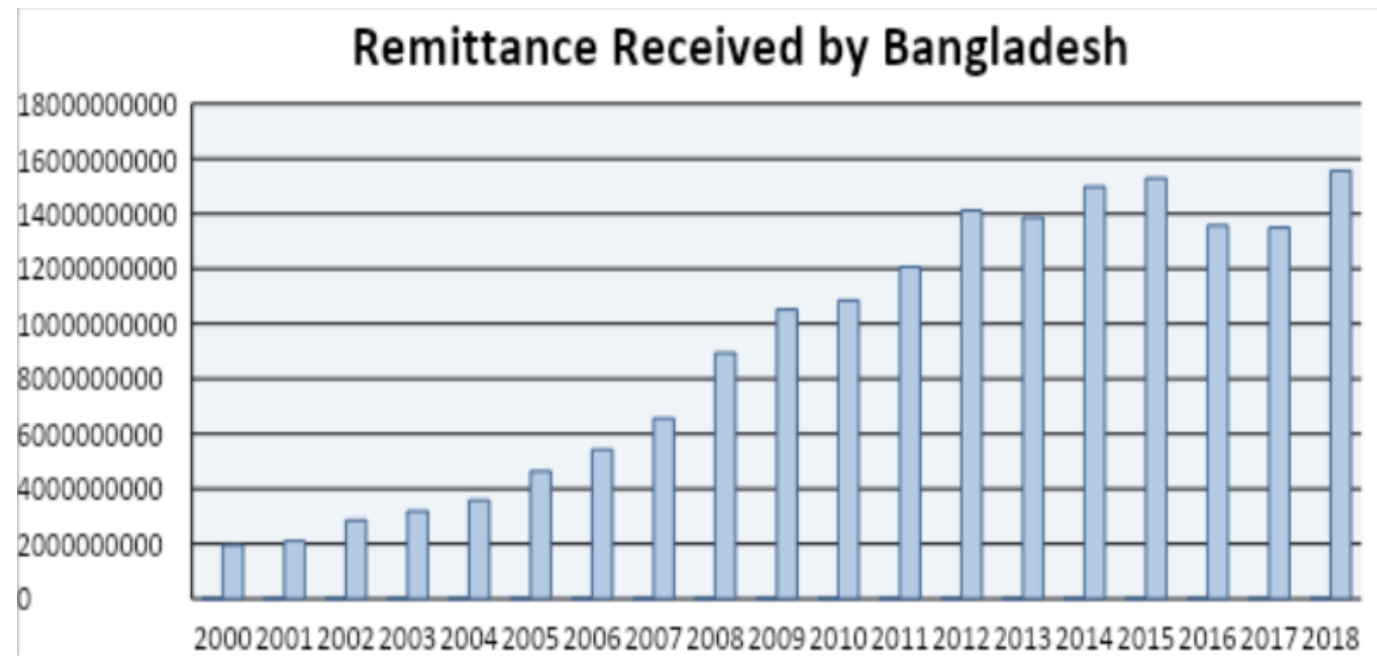

Figure 2.Bangladesh remittance trend

Source: Author's estimate

\subsection{Pakistan's Remittance Trend}

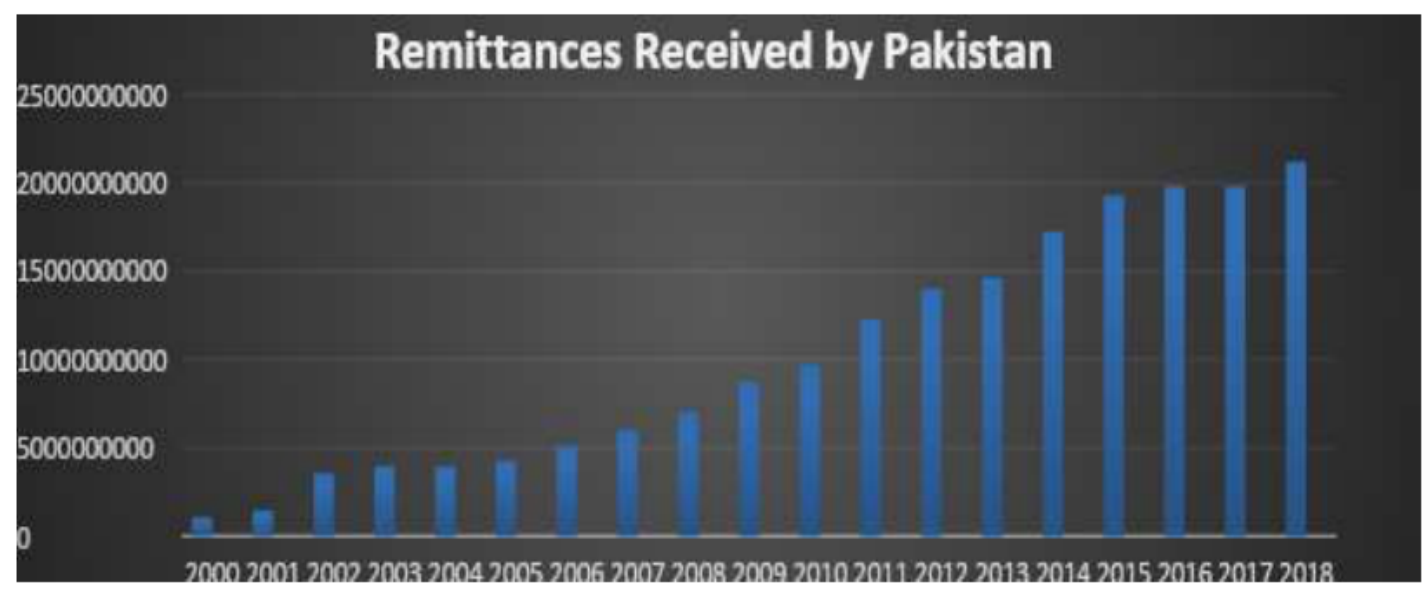

Figure 3. Pakistan's remittance trend

\section{Source: Author's estimate}

There has been increase in remittance inflow after nine eleven. The increase was observed significantly .In 2002, approximate $\$ 3.5$ billion recorded which was doubled than in the year of 2000 and it reached up approximate $\$ 10$ billion in 2010 and $\$ 19.3$ billion in 2015 according to World Bank. In 2018, Pakistan received \$ 20 billion according to the same sources and the due to increase in remittances, there was obvious increase in GDP ratio which is 5.79 5. There was little pause observed in remittance inflow due to some economic down turn in Middle East from 2007 to 2009, as a result, some Pakistani workers were lay off from their work. However, this impact was replaced by the migrant workers aspired for new destinations especially in emerging market. There is one more reason which conveys that global economic crisis did not impact the flow of remittances to Pakistan which is weakening of Pakistani currency implied the consumer's surplus increased when buying was done locally in Pakistan.

\section{ANALYSIS-INTERPRETATION}

South Asia is holding very strong position in various regions. In 2014, the formal remittance reached up to 115 billion \$ with increase $13.5 \%$ and gone up to 132 billion \& in 2018 . 
Moreover, the volume of GDP has major impact of remittances in across South Asian region. For instance, India had share of $2.7 \%$ with 12 billion $\$$ amount of remittances. Bangladesh had 3.6\% GDP with 1.9 billion \$ and Pakistan had $1.4 \%$ with 1.07 billion $\$$ in 2000 from it Diaspora.. As the volume of remittance increased with every passing year, there was also increase witnessed in the volume of GDP. It is very important to mention that some political instability was observed in across the region which resultantly affected the flow of remittances, but later on it got sound environment. For instance, India had 80 billion \$. Bangladesh had 16 billion \% and Pakistan had 20 billion $\$$ with share of GDP $7.7 \%, 7 \%$ and $5.79 \%$ respectively in 2018 . Another important role played by remittances is to finance trade deficit in South Asia especially in Bangladesh. For example, remittances accounted for $\mathbf{2 0 7 . 4 \%}$ merchandise trade deficit for Bangladesh and $\mathbf{9 1 . 3 \%}$ for Pakistan.

\section{CONCLUSION}

It is very clear for economic growth the link between remittances and financial development is very important. To promote the economic prosperity, productive investment through remittance is inflow is very much helpful. During the last decade, remittances have increased with pace in Pakistan, India and Bangladesh . The remittances are usually examined at micro and macro levels in the developmental impacts of remittances. Local effects especially the migrant families their communities are focused in Micro-level studies, while Macro-level studies generally focus on national outcomes (e.g., foreign exchange and labor patterns). It has been observed by some financial institution such as World Bank that devalue of home currency is one of the reason in flow of remittances by the migrants to purchase durable assets e.g., houses and land etc. Moreover, improved financial institution may encourage recipient families to deposit in banks. In this way, this deposit is added to formal remittance flow which was not counted before.

\section{REFERENCES}

[1] IOM. (2005). World Migration Report. Geneva: International Organization of Migration.

[2] Klooster, D. J. (2005). "Producing social nature in the Mexican countryside." Cultural Geographies, 12 (4), 321-344.

[3] Newland, K. (2005). The governance of international migration: mechanisms, processes and institutions, || Paper prepared for the Policy Analysis and Research Programme of the Global Commission on International Migration. Geneva: GCIM.

[4] Paola, G., \& Ruiz-Arranz, M. (2006). Remittances, financial development, and growth. Journal of Development Economics, 144-152.

[5] Pradhan, G., Upadhyay, M., \& Upadhyaya, K. (2008). Remittances and Economic Growth in Developing Countries. The European Journal of Development Research, 20 (3).

[6] Ratha, D. (2007). Leveraging Remittances for Development. Washington: Migration Policy Institute.

[7] Mohapatra, a. e. (2010). Outlook for Remittance Flows 2011-12: Recovery After the Crisis, But Risks Lie Ahead', Migration and Development Brief 13, Migration and Remittances Unit, World Bank, Washington, DC. Washington D.C: World Bank.

[8] United Nations Economic and Social Commission for Asia and the Pacific (UNESCAP) (2010) Economic and Social Survey, 2010, UNESCAP, Bangkok 
[9] De S.; Islamaj E.; Kose A. \& Yousefi S. R. (2016). Remittances over the business cycle: theory and evidence, CAMA Working Papers 2016-13, Centre for Applied

[10] Macroeconomic Analysis, Crawford School of Public Policy, The Australian National University.

[11] Matuzeviciute, K., \& Butkus, M. (2016). Remittances, development level, and longrun economic growth. Economies, 4(4), 28. doi: 10.3390/economies4040028

[12] http://www.pewglobal.org/2015

[13] Rihan, S. (2009). Migration, Remittances and Development in Bangladesh. Colombo. Srilanka: Institute of Policy Studies.

[14] IMF. (2009). Do Workers' Remittances Promote Economic Growth? Washington: International Monetary Fund.

[15] World Bank. (2010). World Bank's Global Remittance Price Database. World Bank.

[16] World Bank. (2011). Migration and Remittance Factbook. World Bank. 